\title{
Keefektifan Pelatihan Kontrol Diri Siswa SMP Melalui Permainan Cublak-Cublak Suweng
}

\author{
Fitri Widya Ningsih ${ }^{1}$, Muslihati ${ }^{1}$, Nur Hidayah ${ }^{1}$ \\ ${ }^{1}$ Bimbingan dan Konseling-Universitas Negeri Malang
}

\section{INFO ARTIKEL}

\section{Riwayat Artikel:}

Diterima: 24-06-2019

Disetujui: 12-10-2020

\section{Kata kunci:}

self control;

traditional game;

cublak-cublak suweng;

kontrol diri;

permainan tradisionaL;

cublak-cublak suweng

\section{Alamat Korespondensi:}

Fitri Widya Ningsih

Bimbingan dan Konseling

Universitas Negeri Malang

Jalan Semarang 5 Malang

E-mail: fitri.widya.1601118@students.um.ac.id

Siswa SMP dalam SKKPD (standard kompetensi kemandirian peserta didik) mempunyai tugas-tugas perkembangan yang dapat dicapai sesuai dengan karakteristik perkembangan remaja awal. Tugas-tugas perkembangan tersebut antara lain landasan hidup religius, landasan perilaku etis, mampu mengelola emosi, kematangan intelektual, sadar akan tanggung jawab terhadap sosial, kesadaran gender, diri pribadi yang mengalami peningkatan, bertingkah laku mandiri secara ekonomi, pengetahuan dan kesiapan karir, dan tercapai hubungan teman sebaya (ABKIN, 2007). Tugas-tugas perkembangan tersebut secara spesifik, meliputi mampu membina hubungan persahabatan yang baik, mampu berperan dengan lingkungan sesuai jenis kelamin, dapat menerima keadaan dirinya dan menggunakannya secara optimal, mencapai kebebasan emosional dari orangtua dan orang dewasa lainnya, menyiapkan diri untuk hidup berumahtangga, menyiapkan diri untuk karirnya, menggapai nilai dan etika terhadap perilaku siswa, dan menggapai perilaku yang dapat bertanggungjawab terhadap sosial (ABKIN, 2007). Pada prosesnya, tugas-tugas perkembangan siswa SMP tersebut tidak selalu dicapai dengan mudah dan tanpa hambatan.

Faktor-faktor yang memengaruhi pencapaian tugas perkembangan, meliputi (1) mampu membina persahabatan yang sesuai, (2) terpenuhinya bersosial sesuai jenis kelamin, dan (3) menerima keadaan fisiknya dan digunakan semestinya. Hal tersebut sangat berkaitan dengan kontrol diri siswa dalam melangsungkan kehidupan sehari-hari. Faktor kontrol diri seseorang terdiri dari faktor internal dan eksternal (Piquero et al., 2016; Richards, 1978). Keadaan yang tidak terduga dan lingkungan yang beragam menjadikan remaja mampu mengendalikan diri. Remaja yang mempunyai keterampilan kontrol diri mampu menerima situasi yang ada di luar dirinya (Bolger, Meldrum, \& Barnes, 2018).

Adanya faktor "tersebut" dapat diminimalisir melalui beberapa keterampilan dasar siswa SMP. Keterampilan tersebut antara lain locus of control (LOC) penyebab situasi atau kejadian dalam hidup mengacu pada persepsi atau orientasi seseorang (Anderson, Hattie, \& Hamilton, 2005; Sagone \& Caroli, 2014). Kontrol diri mereka terhadap situasi bergantung respon individu terhadap suatu situasi yang menekan (Achtziger \& Bayer, 2018). Persepsi berpengaruh terhadap peningkatan motivasi, keinginan yang ingin dicapai, harga diri, perilaku penerimaan terhadap resiko, pengambilan keputusan dan berpengaruh terhadap tindakan yang dilakukan dari perbuatannya (Vaughan, Bouffard, \& Piquero, 2017). Kontrol diri merupakan bagian 
psikologis yang mencakup tiga konsep tentang keterampilan mengontrol diri ialah kemampuan remaja untuk mengubah tingkah laku, memahami informasi yang sesuai maupun yang tidak dengan menginterpretasi serta mampu mengambil tindakan berlandaskan sesuai yang dimengerti oleh remaja tersebut (Averill, 1973; Lindner, Nagy, \& Retelsdorf, 2018). Kontrol diri memiliki manfaat kondisi yang nyaman terhadap diri pribadinya, mampu menghargai, dapat dipercaya dan penuh tanggung jawab pribadi sehingga remaja mampu mengendalikan diri dengan baik di setiap kondisi (Błachnio \& Przepiorka, 2016; Lindner et al., 2018).

Rambe, Mudjiran \& Marjohan (2017) menyatakan kontrol diri dapat ditingkatkan melalui layanan informasi, dalam penanganan kontrol diri rendah menggunakan layanan informasi untuk mereduksi kontrol diri siswa yang rendah di sekolah. Kontrol diri perlu dimiliki oleh individu memperoleh akibat positif yang sesuai dan mengatasi akibat negatif. Seperti pada penelitian Widiana \& Hidayat (2004) mengungkapkan bahwa individu perlu kontrol diri yang meningkat agar bisa mengatur dalam menggunakan internet secara berlebihan. Bimbingan dan konseling pada akhirnya perlu merumuskan metode yang sesuai untuk mencapai peningkatan Kontrol diri siswa SMP. Metode bimbingan kelompok yang bersifat preventif-developmental menjadi salah satu metode yang sesuai dengan tujuan peningkatan kontrol diri siswa SMP. Ada beberapa teknik dan salah satunya didalam bimbingan kelompok adalah teknik permainan.

Teknik permainan dalam bimbingan kelompok akan memberikan instructional effect dan nurturrant effect (Joyce, Weil, \& Calhoun, 2015). Instructional effect merupakan dampak utama yang ditimbulkan secara nyata melalui materi yang digunakan didalam permainan. Nurturrant effect muncul sebagai dampak pengiring dari proses permaianan yang menjadi pendukung dan penguat materi yang diberikan kepada siswa. Adanya kedua dampak tersebut menjadi sesuai untuk digunakan dalam proses peningkatan kontrol diri siswa SMP.

Permainan yang dapat menjadi alternatif untuk digunakan menjadi lebih baik apabila menggunakan permainan tradisional. Penggunaan permainan tradisional didasarkan pada sifat permainan tradisional yang memiliki nilai-nilai luhur Indonesia. Salah satu permainan tradisional dengan nilai-nilai luhur Indonesia yang mendukung proses peningkatan kontrol diri siswa adalah permainan Cublak-cublak suweng. Permainan Cublak-cublak suweng ialah permainan yang berkembang di daerah Jawa, terutama Jawa Tengah, Yogyakarta, dan Jawa Timur. Cublak-cublak suweng ialah sebuah lagu dolanan anak-anak di Jawa yang diciptakan sekitar tahun 1442, oleh Syeh Maulana Ainul Yakin atau lebih dikenal sebagai Sunan Giri. Permainan cublak-cublak suweng mempunyai makna tentang nilai-nilai utama hidup manusia. Permainan ini mengajarkan kehidupan sejak kecil dan mengandung banyak makna. Permainan Cublak-cublak suweng memiliki aspek-aspek dalam meningkatkan kontrol diri. Mengontrol perilaku saat siswa berperilaku sesuai aturan permainan, pemain menunjukkan perilaku yang netral tidak mencurigakan ketika menyimpan suweng. Mengontrol kognitif saat pemain yang memegang batu perlu mempersiapkan kognitifnya untuk menjawab kartu. Mengontrol keputusan pada saat jadi penebak harus siap memutuskan untuk menebak batu yang disembunyikan.

Paparan gagasan di atas memunculkan urgensi utama untuk meningkatkan kontrol diri siswa SMP. Dengan demikian, perlu adanya sebuah pengembangan teknik layanan bimbingan kelompok yang melalui permainan Cublak-cublak suweng untuk meningkatkan kontrol diri siswa SMP. Pengembangan permainan Cublak-cublak suweng ini memiliki tujuan menjadi alternatif konselor dalam memberikan bantuan layanan untuk meningkatkan kontrol diri siswa SMP.

\section{METODE}

Pengujian keefektifan permainan cublak-cublak suweng untuk melihat peningkatan kontrol diri siswa SMP dilakukan menggunakan metode penelitian eksperimen semu atau quasi experimental. Eksperimen tersebut dilakukan melalui desain eksperimen one group pretest-posttest design. Pemilihan desain eksperimen didasarkan pada tujuan rancangan one group pretest-posttest pada pengubahan kondisi pola perilaku atau proses internal yang sangat stabil dan tidak mungkin berubah tanpa usaha yang signifikan (Creswell et al., 2003). Pada penelitian ini, dilakukan pengujian terhadap kelompok utama menggunakan intervensi permainan cublak-cublak suweng dan pengukuran kontrol diri siswa pada nilai pretest dan posttest.

Subjek penelitian merupaka 8 siswa SMP di kota Malang yang akan diberikan pretest, posttest dan intervensi permainan cublak-cublak suweng. Instrumen yang digunakan antara lain skala kontrol diri dan bahan perlakuan berupa panduan pelatihan kontrol diri melalui permainan cublak-cublak suweng bagi siswa SMP. Skala kontrol diri digunakan dalam tahap pretest maupun posttest untuk mengukur tingkat kontrol diri siswa. Panduan pelatihan kontrol diri melalui permainan cublakcublak suweng sebagai bahan perlakuan digunakan sebagai intervensi yang akan diimplementasikan kepada para siswa subjek penelitian.

Data utama dari pelaksanaan eksperimen ini adalah hasil pretest dan posttest siswa. Data tersebut merupakan data tingkat kontrol diri siswa yang diukur melalui skala kontrol diri siswa SMP. Data pretest dan posttest selanjutnya dilakukan analisis secara statistik untuk mendapatkan bukti keefektifan pemberian perlakuan permaian cublak-cublak suweng. Analisis dilakukan melalui pengujian perbedaan pretest dan posttest menggunakan uji wilcoxon. Selain menggunakan uji wilcoxon, analisis juga dilanjutkan untuk mendapatkan bukti signifikansi perbedaan perilaku asertif siswa dalam pretest dan posttest Analisis kedua dilakukan menggunakan pengujian paired samples t-test. 


\section{HASIL}

Paparan data hasil uji coba diikuti turut disertai dengan analisa dan interpretasi. Uji keefektifan produk dilakukan menggunakan one-group pretest posttest design. Uji keefektifan produk ini melibatkan delapan orang siswa yakni dari R_1, R_2, R_3, R_4, R_5, R_6, R_7, R_8 seperti pada tabel di bawah. Pengambilan delapan orang siswa didasarkan pada hasil pretes yang telah dilaksanakan sebelumnya. Setelah pretest dilaksanakan, diberikan treatment kepada delapan orang siswa. Treatment berupa pemberian layanan bimbingan kelompok berupa pelatihan kontrol diri melalui permainan Cublak-cublak suweng untuk peningkatan kontrol diri dari masing-masing siswa. Setelah treatment diberikan, peneliti melakukan posttest terhadap keenam siswa tersebut. Pada tabel 1 menunjukkan hasil dari skor pelaksanaan pretest dan posttest serta selisih (gain).

Tabel 1. Selisih Skor Pretest dan Posttest kontrol diri siswa SMP

\begin{tabular}{ccccc}
\hline Responden & Skor Pretest & Skor Posttest & Selish (Gain) & Persentasi Perubahan \\
\hline R_1 & 81 & 84 & 3 & $0.037 \%$ \\
R_2 & 96 & 102 & 6 & $0.063 \%$ \\
R_3 & 72 & 74 & 2 & $0.028 \%$ \\
R_4 & 76 & 76 & 0 & $0.000 \%$ \\
R_5 & 73 & 76 & 3 & $0.041 \%$ \\
R_6 & 84 & 90 & 6 & $0.071 \%$ \\
R_7 & 88 & 95 & 7 & $0.080 \%$ \\
R_8 & 96 & 105 & 9 & $0.094 \%$ \\
\hline
\end{tabular}

Hasil uji keefektifan dilakukan analisa dengan pengukuran selisih hasil antara pretest dan postest. Selisih dari pretest dan postest menunjukkan dampak treatment yang diberikan peneliti. Hasil pengukuran selisih dapat dilihat pada gambar grafik pretest dan postest dari siswa subjek penelitian (gambar 1).

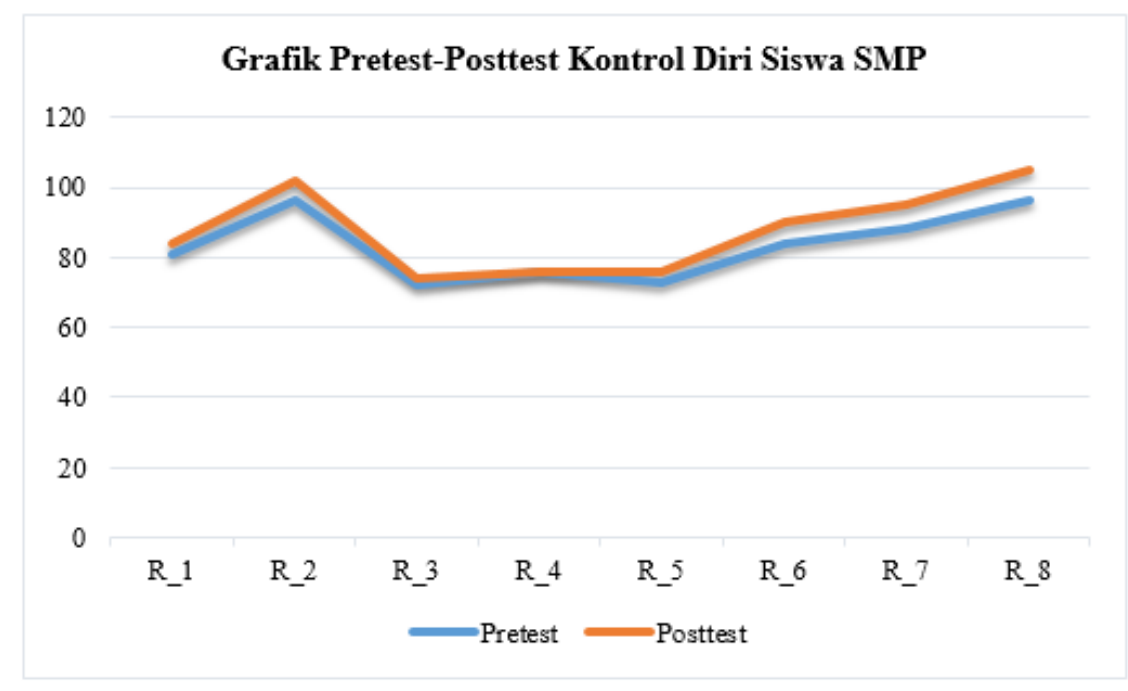

\section{Gambar 1. Contoh grafik garis menggunakan warna yang kontras baik di layar komputer}

Hasil pretest dan postest ditindak lanjuti dengan melakukan analisis wilcoxon untuk mengetahui signfikansi perubahan siswa setelah treatment. Nilai yang digunakan adalah skor keseluruhan skala kontrol diri siswa. Pengujian wilcoxon ini dilakukan menggunakan aplikasi IBM SPSS Ver. 21. Hasil pengujian wilcoxon pada tabel memberikan hasil pada Asymp. Sig. (2-tailed) dengan skor 0.01. Nilai tersebut menunjukkan bahwa terdapat perbedaan antara hasil pretest dan postest pada kontrol diri siswa dikarenakan nilai tersebut berada di bawah 0.05 .

Tabel 2. Pengujian Wilcoxon pada hasil penelitian pengembangan

\begin{tabular}{lc}
\hline Koefisien & Hasil Uji Wilcoxon \\
\hline Nilai Z & $-2.375^{\mathrm{b}}$ \\
Nilai signifikansi Asymp (2-tailed) & .018 \\
\hline
\end{tabular}


Selanjutnya dilakukan pengujian melalui paired t-test untuk melihat signifikansi perubahan yang dialami siswa hasil dari pemberian perlakuan. Pengujian paired t-test ini memberikan hasil berupa Sig. (2-tailed) dalam nilai 0.001. Nilai tersebut berada dibawah angka 0.05 menunjukkan adanya perbedaan yang signifikan dari perlakuan yang diberikan.

Tabel 3. Pengujian Paired Samples T-Test penelitian dan pengembangan

\begin{tabular}{lc}
\hline Koefisien & Hasil Uji T Berpasangan \\
\hline Signifikansi (2-tailed) & 0.004 \\
\hline
\end{tabular}

Pengujian wilcoxon menunjukkan adanya peningkatan yang dialami siswa terkait kontrol dirinya. Pengujian paired $t$ test memperkuat serta menunjukkan bahwa perlakuan yang diberikan berupa bimbingan kelompok terkait kontrol diri melalui permainan cublak-cublak suweng memiliki perbedaan signifikan pada peningkatan kontrol diri siswa.

\section{PEMBAHASAN}

Keefektifan pelatihan kontrol diri melalui permainan cublak-cublak suweng untuk meningkatkan kontrol diri siswa ini berdasarkan penelitian sebelumnya. Penelitian-penelitian tersebut antara lain Rusmana (2010) dan Lacksana (2017) permainan tradisional congklak yang bersifat kearifan lokal memberikan perhatian besar dalam membangun dan menguatkan karakter anak. Selain itu produk layanan bimbingan dan konseling melalui permainan juga turut dilakukan penelitian oleh Putri (2018) sebuah layanan bimbingan yang menyenangkan agar siswa terasa tertarik, salah satu alternatif layanan bimbingan yang menggembirakan adalah pengembangan sebuah panduan permainan ular naga bermuatan nilai budaya Bengkulu untuk meningkatkan Self Advocacy siswa SMP.

Permainan tradisional yang menjadi salah satu kearifan lokal yang dapat dijadikan media dalam memperkuat karakter remaja melalui layanan bimbingan dan konseling (Perianto, 2018). Indonesia dengan yang memiliki berbagai macam budaya tentu akan memiliki berbagai kearifan lokal dengan nilai-nilai positif yang diakui masyarakat (Hanafi, Hidayah, \& Mappiare, 2018). Kearifan lokal merupakan salah satu aspek yang perlu diperhatikan dalam memberikan layanan bimbingan dan konseling yang sesuai dengan budaya siswa di Indonesia (Hidayah, Ramli, \& Hanafi, 2017). Dengan demikian, praktisi mampu memberikan layanan bimbingan konseling yang sesuai dengan budaya siswa di Indoneisa dan menyenangkan melalui permainan cublak-cublak suweng.

Bimbingan dan Konseling memiliki tujuan memfasilitasi siswa untuk mampu mencapai kompetensi perkembangan dan perilaku yang diharapkan. Salah satu fungsi dalam bimbingan dan konseling adalah preventif developmental. Pelayanan bimbingan yang diberikan akan menjadikan siswa lebih berwawasan dan memberikan pengalaman sebagai bekal dirinya bersikap. Alternatif layanan bimbingan yang menyenangkan adalah dengan menggunakan teknik permainan yang mudah dimengerti dan familiar oleh siswa (Putri et al., 2018). Salah satunya yang perlu dikembangkan sebagai salah satu warisan budaya adalah permainan tradisional. Pelestarian permainan tradisional dapat dilakukan dengan memanfaatkannya sebagai media bimbingan kelompok.

Bimbingan kelompok adalah kegiatan yang dilakukan beberapa orang untuk bertukar informasi melalui aktifitas kelompok yang membahas berbagai masalah pribadi, sosial, belajar dan karir. Bimbingan kelompok dapat dilaksakan dalam tiga kelopok yaitgu kelompok kecil, kelompok sedang dan kelompok kelas (Marjo et al., 2017). Tahap dalam bimbingan kelompok ditentukan oleh pengenalan teori yang menjadi penerapan model. Pemberian layanan bimbingan kelompok berdasar pada situasi, keadaan dan kebutuhan siswa. Pada penelitian yang dilakukan peneliti ditemukan tingkat kontrol diri yang rendah pada siswa. Kecenderungan siswa untuk selalu berinteraksi dengan teman sebayanya di sekolah akan menimbulkan beberapa persoalan bagi siswa, salah satunya pada kontrol diri (Mori \& Hayashi, 2006).

Kontrol diri bisa dipahami sebagai pengendalian perilaku untuk menyusun, membimbing, mengelola, dan mengarahkan tindakan tingkah laku yang dapat mengarahkan remaja atau individu yang optimal (Aviyah \& Farid, 2014). Berk dalam Gunarsa (Gunarsa, 2004) Kontrol diri dapat dipahami kemampuan remaja untuk mengendalikan keingintahuan atau perilaku yang bertentangan yang sesuai dengan norma yang ada dilingkungan sosial. Peningkatan kontrol diri melalui permainan tradisional dapat dilakukan dengan menyenangkan karena dalam situasi bermain. Seperti pada penelitian Lacksana (2017) menggunakan permainan congklak dalam menguatkan karakter siswa.

Bermain adalah salah satu hal yang menjadi penting karena bermain ini akan menjadi sebuah media pedagogik yang efektif untuk transfer value, dalam ilmu pendidikan dan sebagai sarana transfer knowledge. Selain itu, permainan sebagai suatu aktivitas kegiatan yang dapat mendatangkan kesenangan bagi individu, serta dalam permainan dibebaskan tanpa ada paksaan dan bermain dengan suka rela (Yusoff et al., 2018). Keanekaragaman budaya yang dimiliki Indonesia mulai dari lagu daerah, makanan khas, tarian tradisional hingga permainan tradisional. Mendorong banyak peneliti untuk melestarikan budaya asli Indonesia dalam program bimbingan dan konseling yang secara spesifik pada lingkup bimbingan kelompok dengan menggunakan permainan tradisional. Seperti pada penelitian Lacksana (2017) tentang permainan congklak dalam penguatan karakter peserta didik. Permainan congklak siswa dapat menginternalisasi nilai-nilai positif pada permainan seperti pengakuan dalam menerima kekalahan. Karakter siswa yang supportif sangat dibutuhkan dalam perkembangannya. 
Berdasarakan hasil penelitian Lacksana (2017) dapat memperkuat permainan tradisional cublak-cublak suweng sebagai media pemberian layanan bimbingan kelompok kepada siswa. Bahwa permainan tradisional cublak-cublak suweng memiliki kelayakan sebagai media untuk bimbingan kelompok. Kelayakan ini juga diperkuat dengan penelitian Putri (2018) dengan permainan tradisional ular naga untuk meningkatkan self advocacy. Siswa dapat belajar mengenai self advocacy melalui permainan ular naga tersebut.

\section{SIMPULAN}

Pengujian pelatihan kontrol diri siswa SMP melalui permaianan cublak-cublak suweng menunjukkan adanya bukti keefektifan atas hasil pengukuran pretest dan posttest. Bukti keefektifan ini menunjukkan bahwa pelatihan kontrol diri melalui permainan cublak-cublak suweng untuk meningkatkan kontrol diri siswa SMP dapat menjadi alternatif layanan yang telah berterima secara praktis untuk digunakan sebagai teknik bimbingan dan konseling oleh guru BK.

Pengujian keefektifan telah dilakukan secara terbatas pada subjek di satu sekolah di Kota Malang. Beberapa sekolah lain yang memiliki siswa berlatar belakang masalah yang berbeda dimungkinkan memiliki perbedaan keefektifan dari pelatihan kontrol diri melalui permainan cublak-cublak suweng pada siswa SMP. Saran yang diberikan adalah dilakukannya pengujian lebih lanjut terkait keefektifan produk terhadap siswa-siswa pada lingkup sekolah yang lebih luas maupun dengan sasaran yang berbeda di luar kota Malang. Hasil penyesuaian tersebut akan memperkuat bukti keefektifan pada hasil penelitian ini.

\section{DAFTAR RUJUKAN}

ABKIN. (2007). Rambu-rambu Penyelenggaraan Bimbingan dan Konseling Dalam Jalur Pendidikan Formal. Jakarta: Depatemen Pendidikan.

Achtziger, A., \& Bayer, U. C. (2018). Self-Control Mediates The Link Between Gender and Academic Achievement in SexStereotyped School Subjects in Elementary and in Higher Secondary Schools. Current Psychology, 1-13.

Anderson, A., Hattie, J., \& Hamilton, R. J. (2005). Locus of Control, Self-Efficacy, and Motivation in Different Schools: Is moderation the key to success? Educational Psychology, 25(5), 517-535.

Averill, J. R. (1973). Personal Control Over Asversive Stimuli and Its Relationship to Stress. Psychological Bulletin, 80(4), 286-303.

Aviyah, E., \& Farid, M. (2014). Religiusitas, Kontrol Diri, dan Kenakalan Remaja. Persona: Jurnal Psikologi Indonesia, 3(2), $126-129$.

Błachnio, A., \& Przepiorka, A. (2016). Dysfunction of Self-Regulation and Self-Control in Facebook Addiction. Psychiatric Quarterly, 87(3), 493-500.

Bolger, M. A., Meldrum, R. C., \& Barnes, J. C. (2018). The Contribution of Maternal and Paternal Self-Control to Child and Adolescent Self-Control: A Latent Class Analysis of Intergenerational Transmission. Journal of Developmental and LifeCourse Criminology, 4(3), 251-275.

Creswell, J. W., Clark, V. L. P., Gutmann, M., \& Hanson, W. E. (2003). Advanced Mixed Methods Research Designs. In Handbook of Mixed Methods in Social and Behavioural Research.

Gunarsa, S. D. (2004). Psikologi Perkembangan Anak dan Remaja. Jakarta: Gunung Mulia.

Hanafi, H., Hidayah, N., \& Mappiare, A. (2018). Adopsi Nilai Budaya Osing Dalam Kerangka Meaning of Life. Jurnal Pendidikan: Teori, Penelitian, dan Pengembangan, 3(9), 1237-1243.

Hidayah, N., Ramli, M., \& Hanafi, H. (2017). Urgency Cognitive-Behavioral Counseling based on Local Wisdom for Junior High School Counselor in East Java. Advances in Social Science, Education and Humanities Research, Volume 118. Proceedings of the $9^{\text {th }}$ International Conference for Science Educators and Teachers (ICSET 2017), 923-928.

Joyce, E. C., Weil, M., \& Calhoun, E. (2015). Models of Teaching (9th ed.). New York: Pearson.

Lacksana, I. (2017). Kearifan Lokal Permainan Congklak sebagai Penguatan Karakter Peserta Didik melalui Layanan Bimbingan Konseling di Sekolah. Satya Widya, 33(2), 109-116.

Lindner, C., Nagy, G., \& Retelsdorf, J. (2018). The Need for Self-Control in Achievement Tests: Changes in Students' State Self-Control Capacity and Effort Investment. Social Psychology of Education, 21(5), 1113-1131.

Marjo, H. K., Kartadinata, S., Suherman, U., \& Rakhmat, C. (2017). Rancangan Model Bimbingan Kelompok untuk Mengembangkan Empati Budaya Inklusif Mahasiswa Bimbingan dan Konseling di DKI Jakarta. Proceeding Seminar dan Lokakarya Nasional Bimbingan dan Konseling 2017, 1(0), 58-83.

Mori, J., \& Hayashi, M. (2006). The Achievement of Intersubjectivity Through Embodied Completions: A Study of Interactions Between First and Second Language Speakers. Applied Linguistics, 27(2), 195-219.

Perianto, E. (2018). Kearifan Lokal Sekolah Sebagai Basis Pengembangan Program Bimbingan dan Konseling Komprehensif. Jurkam: Jurnal Konseling Andi Matappa, 2(1), 11-18.

Piquero, A. R., Jennings, W. G., Farrington, D. P., Diamond, B., \& Gonzalez, J. M. R. (2016). A Meta-Analysis Update on the Effectiveness of Early Self-Control Improvement Programs to Improve Self-Control and Reduce Delinquency. Journal of Experimental Criminology, 12(2), 249-264.

Putri, P., Mappiare-AT, A., \& Irtadji, M. (2018). Panduan Permainan Ular Naga Bermuatan Nilai Budaya Bengkulu untuk Meningkatkan Self Advocacy Siswa SMP. Jurnal Pendidikan: Teori, Penelitian, dan Pengembangan, 3(11), $1417-1422$. 
Rambe, S. A., Mudjiran, M., \& Marjohan, M. (2017). Pengembangan Modul Layanan Informasi untuk Mengembangkan Kontrol Diri dalam Penggunaan Smartphone. Konselor, 6(4), 132-137. https://doi.org/10.24036/02017648051-0-00 Richards, C. S. (1978). When Self-Control Fails: A Case Study of The Maintenance Problem in Self-Control Treatment Programs. Cognitive Therapy and Research, 2(4), 397-401.

Rusmana, D. D. A. (2010). Permainan Congklak: Nilai dan Potensinya bagi Perkembangan Kognitif Anak. Patanjala : Jurnal Penelitian Sejarah Dan Budaya, 2(3), 537-549.

Sagone, E., \& Caroli, M. E. De. (2014). Locus of Control and Academic Self-Efficacy in University Students: The Effects of Self-Concepts. Procedia - Social and Behavioral Sciences, 114, 222-228.

Vaughan, T. J., Bouffard, J. A., \& Piquero, A. R. (2017). Testing an Integration of Control Theories: The Role of Bonds and Self-Control in Decision Making. American Journal of Criminal Justice, 42(1), 112-133.

Widiana, S. H., \& Hidayat, R. (2004). Kontrol Diri dan Kecenderungan Kecanduan Internet. Humanitas: Indonesian Psychological Journal, 1(1), 6-16.

Yusoff, Z., Kamsin, A., Shamshirband, S., \& Chronopoulos, A. T. (2018). A Survey of Educational Games as Interaction Design Tools for Affective Learning: Thematic Analysis Taxonomy. Education and Information Technologies, 23(1), $393-418$. 